\title{
A sensitivity analysis of price formulae
}

\author{
J.J. Doppegieter and I.J. Lambrechts \\ Department of Business Economics, University of Stellenbosch, Stellenbosch
}

This is the last in a series of four articles. In the first article two price formulae were discussed and in the subsequent two articles two methods of analysis were demonstrated. In this article a third method of analysis concerning the sensitivity of some selected model parameters is presented. Four parameters have been selected, i.e. the allowed profitability rate, the inflation rate, the growth rate, and the statutory tax rate. The value of each factor has been increased and decreased by $10 \%$ to test the sensitivity of each. In both price formulae the allowed profitability rate has the highest relative importance, followed by the inflation rate. Furthermore, in price formula $A$ some parameters have no or only a small short-term effect on the internal rate of return, e.g. the statutory tax rate. In addition, the internal rate of return of formula $A$ is generally more volatile to changes in the variables analysed than that of formula B. This type of analysis could be very helpful for negotiations between price/tariff-determining bodies and price-controlled undertakings/industries.

S. Afr. J. Bus. Mgmt. 1985, 16: $181-184$

Hierdie is die laaste in 'n reeks van vier artikels. In die eerste artikel is twee prysformules bespreek en in die volgende twee is twee metodes van ontleding toegelig. In hierdie artikel word 'n derde metode van ontleding, naarnlik die bepaling van die sensitiwiteit van sekere veranderlikes, bespreek. Vier veranderlikes word getoets, te wete die toegelate rentabiliteit, die inflasiekoers, die groeikoers en die statutêre belastingkoers. Die waarde van elke veranderlike word met $10 \%$ verhoog en verlaag om die sensitiwiteit te toets. By beide prysformules is die toegelate rentabiliteit die mees sensitiewe veranderlike, gevolg deur die inflasiekoers. By prysformule $A$ het sommige veranderlikes geen of net 'n klein korttermyn uitwerking op die interne rentabiliteit, byvoorbeeld die belastingkoers. Die interne rentabiliteit van formule $A$ is oor die algemeen meer sensitief vir veranderinge in die waarde van die veranderlikes as formule $\mathrm{B}$. Hierdie metode van ontleding kan waardevol wees vir onderhandelinge tussen prys- of tariefbepalende liggame en prysbeheerde ondernemings/ bedryfstakke.

S.-Afr. Tydskr. Bedryfsl. 1985, 16: $181-184$

\section{J.J. Doppegieter* and I.J. Lambrechts}

Department of Business Economics, University of Stellenbosch, Stellenbosch, 7600 Republic of South Africa

*To whom correspondence should be addressed

\section{Introduction}

In the first article, amongst other things the basic working of the computer models $\mathrm{A}$ and $\mathrm{B}$, designed to simulate price formulae A and B, was explained. In the following two articles two methods of analysis were demonstrated. In this article, the last in the series, a third method of analysis, concerning the sensitivity of some selected model parameters, will be presented.

As the future is uncertain all types of changes could affect the outcome of a price formula. As a result myriad questions are liable to be presented to the financial planner, e.g. what is the effect of changes in the allowed profitability, the interest and the inflation rate. The objective of this article is to discuss and to illustrate a sensitivity analysis of some selected model parameters which are incorporated in price formulae $\mathbf{A}$ and $\mathbf{B}$.

\section{The method of analysis}

From more than 20 model parameters used, four have been selected for analysing the sensitivity, viz.:

- The profitability rate allowed

- The rate of inflation

- The growth rate

- The statutory tax rate

In both models each parameter is increased and decreased by the factor $0,1(10 \%)$. In the first run, for example, the profitability rate allowed, which was originally $15 \%$, is increased by $1,5 \%(0,10 \times 15 \%)$ to $16,5 \%$. In the second the rate is decreased by $1,5 \%$ to $13,5 \%$.

The results are compared with the original results of formulae $A$ and $B$ in order to analyse the incremental effects of the various changes in the parameters. The incremental effects are measured by examining the changes in the internal rates of return.

As all the parameters are changed by the same factor $(0,1)$, an indication of the relative importance of each parameter, that is the degree of sensitivity compared with the others, is obtained. It should be realized, however, that the results are not completely comparable, since in practice the probability of a $10 \%$ change in each parameter will differ.

\section{The results of the research Introduction}

In Table 1 the results of the sensitivity analysis of the four model parameters are shown. The figures represent incremental average (weighted) changes in the internal rate of return owing to marginal changes in the four model parameters.

In the remainder of this article the changes in the four parameters shown in Table 1 will be illustrated and discussed in detail. 
Table 1 The sensitivity of the internal rate of return

\begin{tabular}{|c|c|c|c|c|c|c|c|c|c|c|c|}
\hline \multirow[b]{3}{*}{ Variable } & \multirow[b]{3}{*}{ Change } & \multicolumn{10}{|c|}{ Resultant effect on internal rate of return } \\
\hline & & \multicolumn{5}{|c|}{ Formula A, year: } & \multicolumn{5}{|c|}{ Formula B, year: } \\
\hline & & 1 & 5 & 10 & 15 & 20 & 1 & 5 & 10 & 15 & 20 \\
\hline Profitability rate & $15 \% \pm 1,5 \%$ & $9,9^{\mathrm{a}}$ & 4,5 & 4,7 & 4,7 & 4,1 & 7,1 & 7,6 & 6,9 & 7,0 & 6,9 \\
\hline Rate of inflation & $14 \% \pm 1,4 \%$ & 0,3 & 1,1 & 2,4 & 3,5 & 4,4 & 3,8 & 3,9 & 4,0 & 3,8 & 3,9 \\
\hline Growth rate & $5 \% \pm 0,5 \%$ & 0,3 & 1,1 & 1,2 & 0,9 & 0,3 & 0,3 & 0,3 & 0,4 & 0,3 & 0,4 \\
\hline Statutory Tax Rate & $46 \% \pm 4,6 \%$ & - & $0,6^{* b}$ & $1,8^{*}$ & $2,1^{*}$ & $2,0^{*}$ & $2,0^{*}$ & $2,2^{*}$ & $2,0^{*}$ & $2,2^{*}$ & 2,0 \\
\hline $\begin{array}{l}\text { Original internal rate } \\
\text { of return }\end{array}$ & & 17,7 & 17,8 & 16,9 & 17,0 & 17,2 & 36,6 & 36,9 & 37,0 & 37,1 & 37,1 \\
\hline
\end{tabular}

$9.9 \%$ was calculated as follows:

An increase of $1,5 \%$ in the profitability rate increased the internal rate of return (i.r.r.) by $1,8 \%$.

A decrease of $1,5 \%$ in the profitability rate decreased the i.r.r. by $1,7 \%$.

The average change is therefore:

$\frac{(1,8+1,7) \times 0,5}{17,7}=9,9 \%$

'The asterix indicates the internal rate of return's inverse reaction to the change in the parameter employed, i.e. an increase in the value of the variable results in a decrease of the i.r.r. and vice versa.

'See 'Changes in the tax rate'.

Changes in the allowed profitability rate

The profitability rate allowed is the return on capital provided for in the price formula. In formulae A and B the profitability rate allowed amounts to respectively $15 \%$ before tax and $15 \%$ after tax.

In formula $\mathrm{A}$ a change of $10 \%$ in the allowed profitability rate results in an average change of about $4 \%$ in the internal rate. The comparable figure for formula $B$ is about $7 \%$. The results are illustrated graphically in Figure 1.

As might be expected, the correlation between the profitability rate allowed and the internal rate of return is positive in both formulae. In both formulae the internal rate of return appears to be highly sensitive to changes in the profitability rate allowed. From Table 1 it can be deduced that the profitability rate allowed has the highest relative importance of the four selected parameters.

Formula A's return shows a very high sensitivity over the short term, but over the long term the sensitivity diminishes considerably. In contrast, formula B's rate of return is less sensitive over the short term.
The explanation for this difference is related to differences in tax policies. Owing to granted (investment- and initial) allowances Company A does not pay any tax over the first three years. Therefore, the incremental increase in base return (i.e. the profitability rate allowed times average capital employed) results in year $1-3$ in an equal increase of cash flow. However, from year 4 and onwards the accumulated taxable income is positive and consequently the marginal increase in cash flow is only equal to $(1-46 \%)$ times the incremental increase in base return.

In Company B the granted allowances result in an adjusted (lower) tax rate (22\% in stead of $46 \%$ ) which is constant over its full lifetime, the initial years included. An incremental change in base return therefore results in a constant change of cash flow of $(1-0,22)$ times base return.

\section{Changes in the inflation rate}

The rate of inflation (presumed to be 14\%) has an impact on the current and the fixed assets in the two formulae. A $10 \%$ increase and decrease in the rate of inflation brings about

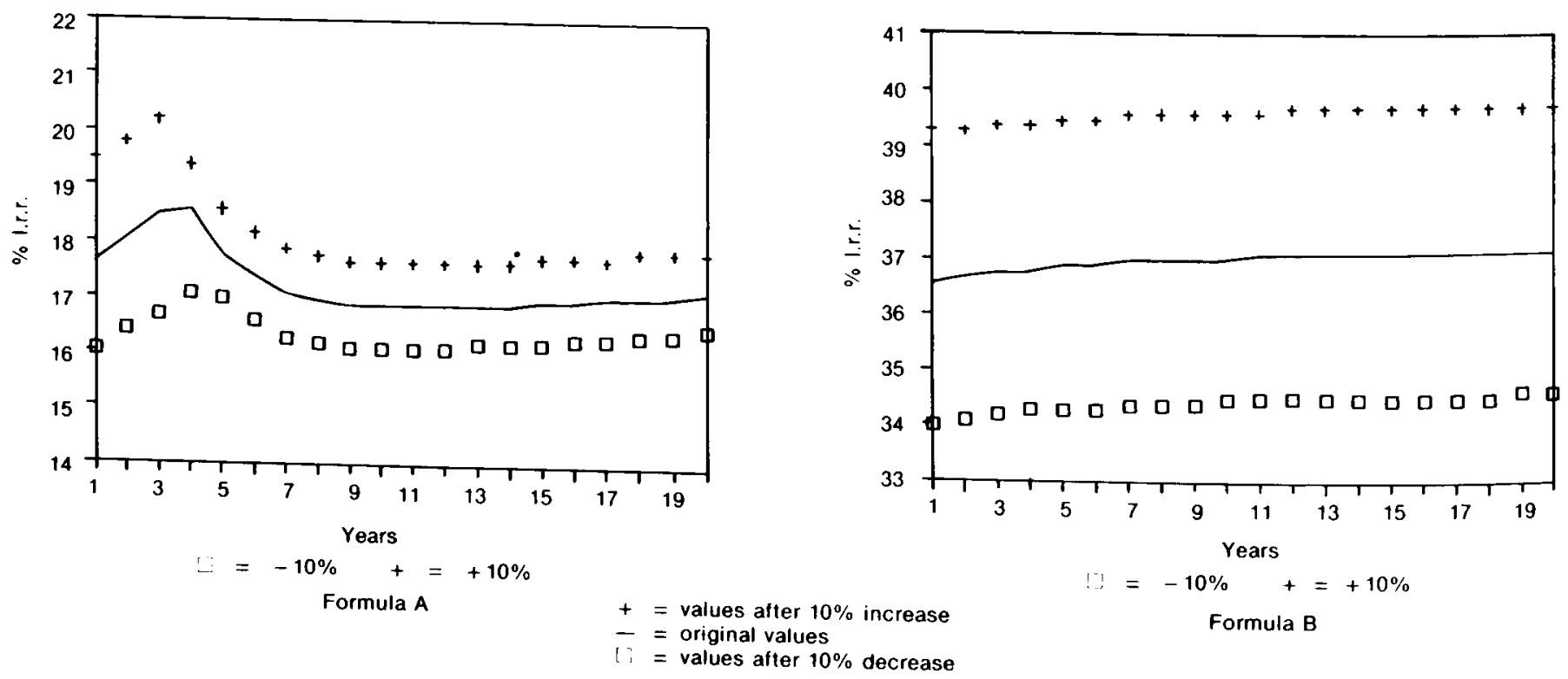

Figure 1 The effect of a $10 \%$ change in the profitability rate allowed on the internal rate of return of formulae A and B 

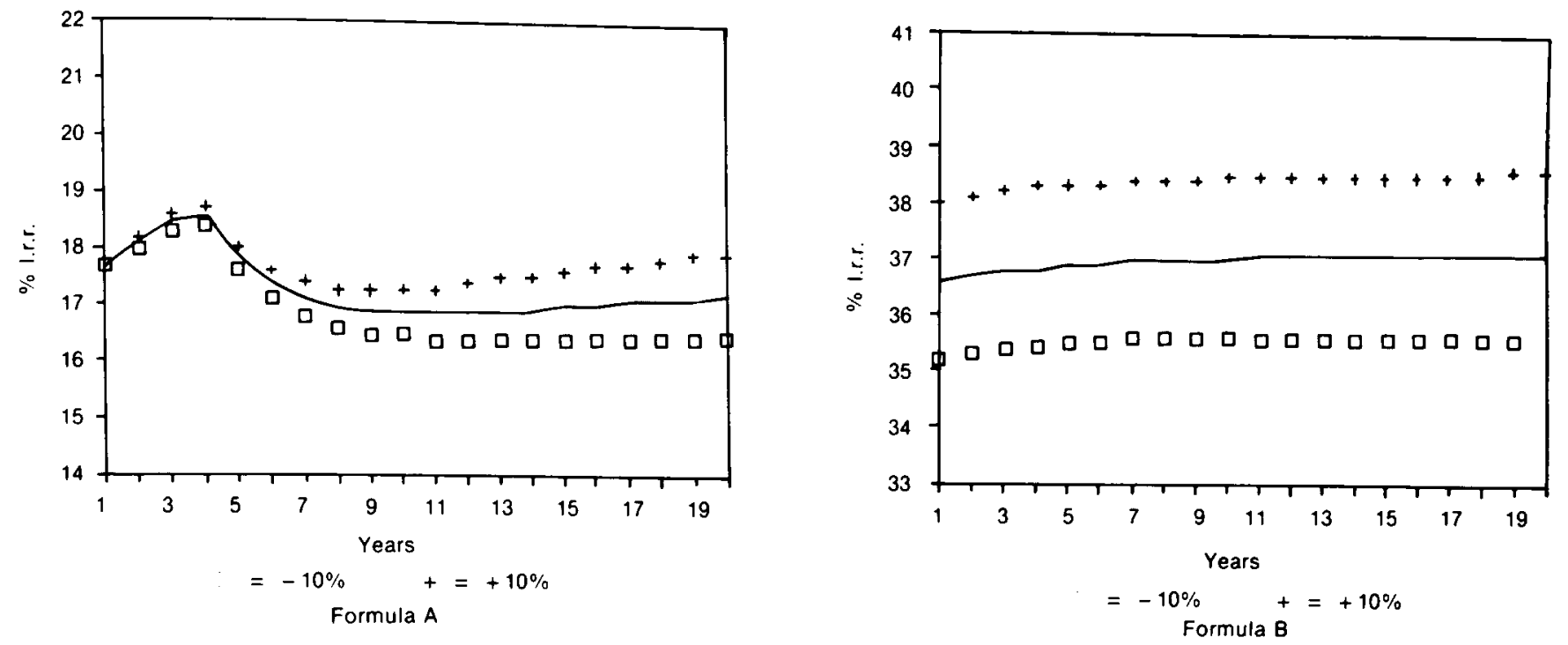

Figure 2 The effect of a $10 \%$ change in the inflation rate on the internal rate of return of formulae $\mathrm{A}$ and $\mathrm{B}$

the following results:

In formula $\mathrm{A}$ the correlation between the rate of inflation and the internal rate of return is positive and the sensitivity of the internal rate of return increases over time. In formula B the correlation is also positive but shows almost no change over the 20 years (see Figure 2).

In both companies the inflation rate has a strong impact on the internal rate of return. The main explanation for the considerable correlation is that the fixed and current assets increase due to inflation, thereby augmenting 'the base return allowed', which is calculated by multiplying the profitability rate allowed with the total assets. The calculated internal rate of return is therefore a monetary rate.

Although companies often suffer severely in times of inflation, the rates of return of both the formulae correlated positively with the rate of inflation, mainly because of the provision for additional depreciation and the absence of a gearing adjustment. From Table 1 two differences between the two formulae can be identified. Firstly, formula A's return is less sensitive than that of formula B. The main explanation is that formula A's fixed assets are valued at historical cost values, whereas in formula $B$ the fixed assets are valued at replacement values (which is, among others, a function of inflation). In other words contrary to formula B, inflation has no impact on the cost of fixed assets of formula A. Since the fixed assets are an important part of the capital employed, from which the base return is determined, it is obvious that, ceteris paribus, formula B's return would be more sensitive, because of inflation, than that of formula A. Secondly, formula A's return becomes more sensitive as a function of time whereas the sensitivity of formula B's return remains more or less unchanged. The reason for this is that in formula A the fixed assets are valued at historical cost, which causes a low sensitivity profile over the short term. Over the longer term, however, the inflation-sensitive asset elements (replacements, expansion investments, and current assets) influence the value of fixed assets more and more, thereby enhancing the sensitivity between the rate of return and inflation.

\section{Changes in the growth rate}

In the two models the growth rate influences capital requirements for expansion of fixed and current assets. The rate, initially $5 \%$, is changed by $\pm 10 \%$ to $4,5 \%$ and $5,5 \%$.

The results show that A's internal rate of return has a positive correlation with the growth rate. Apart from the first year, it changes the internal rate of return by approximately $1 \%$, compared with formula $B$ where the changes vary between $0,3 \%$ and $0,4 \%$ (see Figure 3 ).

Although there is a positive correlation between growth and the internal rate of return this correlation is weak, particularly in comparison with the two parameters discussed previously. This is not surprising because growth affects only a relatively small percentage of total capital employed, that is, expansion investments and net current assets.

\section{Changes in the tax rate}

The analysis of the fourth model parameter brings to light two significant findings. Firstly, over time formula A's return becomes more sensitive whereas formula B's return remains more or less stable. The main explanation for this finding is related to the differences in tax policies (see 'Changes in the allowed profitability rate'). In contrast with company B, company $A$ does not pay tax initially due to an accumulated tax loss. Consequently changes in the tax rate only affect tax paid, cash flow, and the i.r.r. after four years when the accumulated tax loss turns positive. Secondly, although the statutory tax rate of formula $A(46 \%)$ is considerably higher than the effective tax rate of formula B $(22 \%)$, formula B's return is on average more sensitive to changes in the tax rate than that of formula $A$ (Figure 4). (The effective tax rate for formula $A$ is also less than $46 \%$ because of the initial and investment allowances).

\section{Further applications of the sensitivity analysis}

The above illustrated sensitivity analysis can be applied relatively easily in alternative ways.

Firstly, apart from the four parameters studied in this article, more parameters could be incorporated in the analysis, e:g. the interest rate, the dividend coverage ratio, the investment allowance rate, the depreciation allowance rate, etc. Secondly, combinations of related parameters could be tested, e.g. simultaneous changes in the interest rate and the rate of inflation. Thirdly, the sensitivity of the parameters could be studied in a different way by analysing the correlation between the selected parameters and criteria other than the internal rate of return, e.g. cash flow, leverage and liquidity. Fourthly, the magnitude of the incremental changes in the parameters could be altered. Different trends could also be introduced, e.g. cyclical changes i.e. from years 1 to 5 

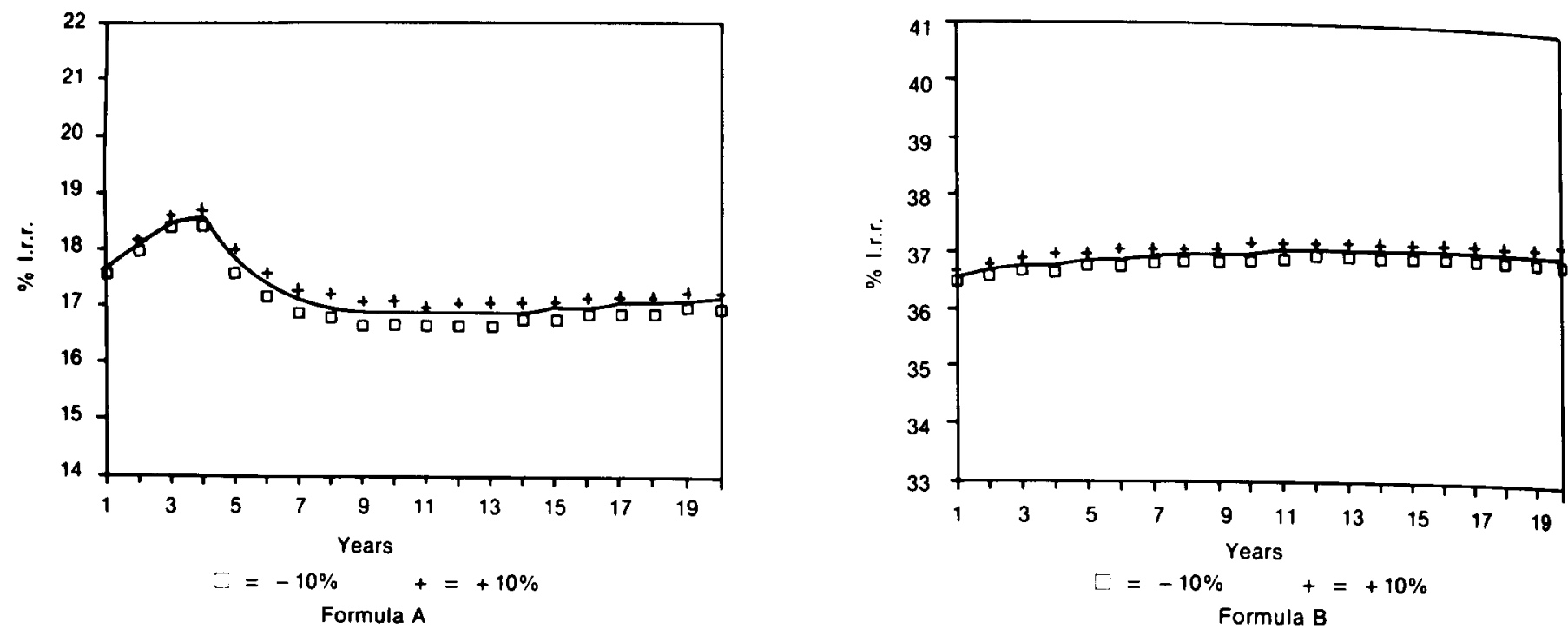

Figure 3 The effect of $\mathrm{a} \pm 10 \%$ change in the growth rate on the internal rate of return (i.r.r.) of formulae A and B
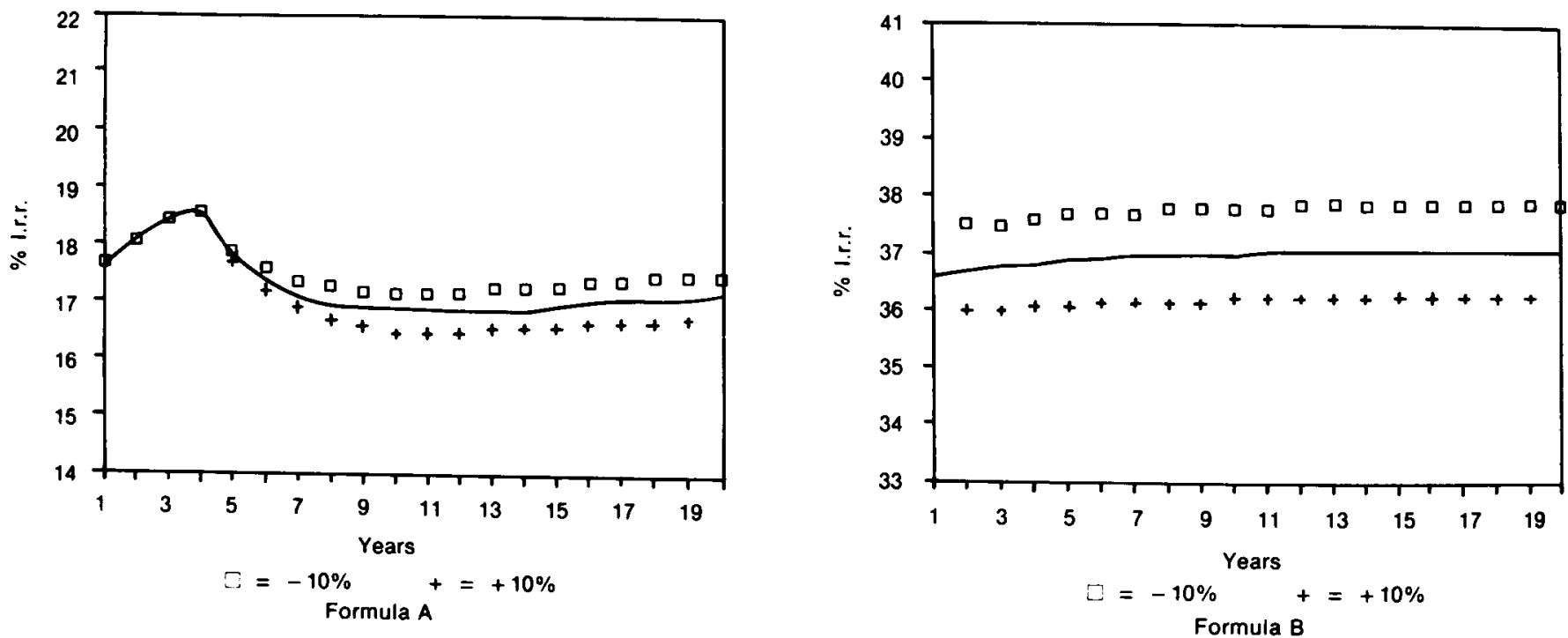

Figure 4 The effect of $a \pm 10 \%$ change in the tax rate on the internal rate of return of formulae $A$ and $B$

amounting to $10 \%$ and $5 \%$ from years 6 to 10 , etc.

Finally, the sensitivity analysis can be adapted to an optimizing model, which is designed to answer questions concerned with 'how can we best do this?'

\section{Summary and Conclusions}

In this fourth article a sensitivity analysis was illustrated and discussed. Four model parameters in respect of price formulae $A$ and $B$ were analysed by examining the effect of marginal changes in these parameters on the internal rate of return of both formulae. Various interesting results emerged.

In both formulae the profitability rate allowed has the highest relative importance, followed by the rate of inflation. Furthermore, in formula A some model parameters have no or only a small short-term effect on the internal rate of return, for example the statutory tax rate. In addition, formula A's return rate, is generally more volatile to changes in the variables analysed than that of formula $B$.

In conclusion, the main advantages of the presented sensitivity analysis appear to lie in stressing the relative importance of model parameters, pointing out the nature of the correlation (positive or negative) between the model parameter and the objective function, as well as providing an indication of the sensitivity as a function of time. It will enable an undertaking to pinpoint and quantify the most relevant financial variables. This is seen as very helpful in the preparation for negotiations between price/tariff-determining bodies and price-controlled undertakings/industries and could result in quicker reactions to changes in their ever-changing environment. 